\section{Research on human embryos}

SIR-I, for one, welcome the recent decision by Dr Louis Sullivan, Secretary of Health and Human Services, to extend the ban on the use of US federal funds to support research on human embryos and fetuses obtained by elective abortion. The statement in your leading article (Nature 342, 104; 1989) that "the question of whether abortion should continue to be allowed ... is a separate question" would obviously be incorrect if elective abortion were illegal. Using tissue obtained from an illegal procedure would presumably itself be illegal. The question of whether it is acceptable to use the abortus for research or other ends arises only because abortion is legal. In fact, if legality were the only consideration, 'anti-abortionists', as you label them, would have to concede that the use of fetal tissue derived from a legal procedure should itself be legal.

Some of us, however, believe that the legality of abortion is irrelevant to its morality, in which case the resolution of the fetal tissue question does not derive strictly from legal issues but must involve determination of the morality of elective abortion. If, as some of us believe, elective abortion can only rarely be defended on moral grounds, then further profit from such acts, either by individuals or by society, is also immoral. The same objection can be, and has been, applied to the use of data from Nazi experiments. However, unlike the Nazi medical data, which are historical, the use of aborted tissue is feasible only if there is a continued practice of abortion.

Thus, my objection to the use of fetal tissue stems from the perceived immorality of the act that leads to its procurement. Is it not ironic that the two properties of human fetal tissue that make it so desirable for medical research and therapy, namely, that it is undeniably human and that it has tremendous developmental potential, are two of the same properties that bring pro-life advocates to the defence of these lives?

On the other hand, if elective abortion can be justified on moral grounds, then let us press boldly onwards with complete freedom for abortion, whether for gender selection or to provide fetal tissue for research or treatment. In fact, if abortion can be justified on moral grounds, I would argue that it would be immoral not to use fetal tissue for all possible benefit, including direct consumption for nutritional purposes. I am somewhat surprised that no movement has appeared among proabortionists in support of abortuses as a food source. Why waste this valuable resource? Some might object that this borders on cannibalism, but that would be the case only if the victims were human. Besides, it is not obvious what moral or legal difference, if any, exists between the maintenance of health and life through human tissue transplantation as opposed to its direct consumption.

KeIth A. CRUTCHER University of Cincinnati Medical Center College of Medicine,

Department of Neurosurgery,

231 Bethesda Avenue,

Cincinnati, Ohio 45267-0515, USA

\section{Women in science}

SIR - As a woman scientist, I should like to comment on the situation of women in West German science.

"If a woman has a special gift - which does not happen very often - I do not think it right to refuse her the chance and means to study . . . but such a case must always be regarded as an exception" (Max Planck, $1897^{1}$ ). In his time, Planck was considered a progressive man to tolerate women in the scientific field. Only in 1908 were women allowed to study in German universities. In 1923, the first woman was nominated professor.

In 1989 , women are still rare in the natural sciences. At universities as well as at research institutes (such as those of the Max-Planck-Society) women are mostly represented as students, technical assistants and secretaries. There are almost no women as team heads or independent researchers. In 1987 , only 6.8 per cent of all researchers in mathematics and natural sciences working in institutes of the MaxPlanck-Society were women ${ }^{2}$. Higher positions are without exception occupied by men. And among the 133 active participants at the spring meeting of the German Physiological Society this year, only three scientists were women.

There are several reasons for the poor representation of women in German sciences. One is the lack of tradition (with some famous exceptions ${ }^{1}$ ). Another, more important, reason is the still patriarchal and authoritarian system of German universities and other scientific institutions. Then there are economic problems The German tax system makes it very unattractive for both partners in a marriage to work. Part-time jobs are almost impossible to get in science. The belief is that if one does not spend 12 hours a day in the laboratory one is not seriously dedicated to science. In this context, the notion that women could simultaneously be traditional mothers, traditional wives and productive scientists seems entirely absurd.

Women are allowed to get a PhD, but who assures them they will find a job afterwards - particularly if they intend to marry and have children? They are confronted with the alternatives of family or career. In fact, most of them leave their jobs when they become mothers.

Paradoxically, Latin countries with 'macho' traditions offer more opportunities for tenure for professional women in almost all academic fields. It is a pity that in a technologically developed country such as Germany, people waste their talent and energy because of a rigid and stereotyped system.

It is to be hoped that a new generation of German academics will have a more open view of the role of women in the scientific community.

MARIA EUgenIA MONETA Mechthildenstr. 19, 8000 München, FRG

1. Walton, A. Chem. Brit. May, 461-462 (1985)

2. Ruschhaupt, U. \& Hartung, D. MPG-Spiegel April 22-26 (1988).

\section{New telescope}

SIR-Steven Dickman's News item "Six feet off the ground" (Nature 341, 177; 1989) gives an inaccurate representation of West German efforts to design a new large telescope (DGT).

Bochum and Göttingen are far from being rivals in the project. It is being pursued jointly by ten astronomical institutes in Germany including university departments, Max-Planck-Institutes and observatories. They cooperate within the DGT Working Group, of which the Göttingen and Bochum University institutes are also members. Alternatives for the telescope mounting such as the two referred to by Dickman are being studied in collaboration with the companies Krupp and MAN following a decision of the working group. The best solution will eventually be selected entirely on its technical and scientific merits. A Ritchie - Chrétien system based on a minimally segmented 12-metre primary containing a central light-weight 8 -metre monolith is the optical configuration at present being explored by the workshop group with Zeiss. There is no race between Krupp and Zeiss: both companies are cooperating in this project. Together with MAN and DSD Dillinger Stahlbau, they are members of the DGT-IndustriesConsortium.

The funding of the project is at present uncertain because West Germany is committed to making large contributions to the European Southern Observatory's Very Large Telescope. Certainly there is not - and cannot be - a race between two small university groups such as Bochum and Göttingen to win a DM200 million project: it can be realized only by a national or - more likely - international effort.

KLAUS J. FRICKE TH. SCHMIDT-KALER

Universitäts-Sternwarte,

Geismarlandstrasse 11 ,

D-3400 Göttingen, FRG 